\title{
DEFOE, DISSENT, AND EARLY WHIG IDEOLOGY
}

\author{
K. R. P. CLARK \\ University of Kansas
}

\begin{abstract}
A B STRACT. The nature of Whig ideology at its formation in the late seventeenth and early eighteenth centuries continues to attract the attention of historians of political thought. This article contends that prevalent understandings of the taxonomy of the subject nevertheless still often remain secular, and do not fully attend to the religious constituencies of the authors involved. One key author was Daniel Defoe, who was credited with several anonymous pamphlets published after the Revolution of I688. The effect of these attributions is to reinforce a homogenized picture of early Whig political ideology that fails to identify differences between authors who used similar terms such as 'contract', 'resistance', and 'natural law'. This article de-attributes certain of these pamphlets, outlines the consequences for the history of political thought of that de-attribution, re-establishes Defoe's own political identity, and proposes that such a taxonomy should give more attention to religious difference.
\end{abstract}

Providence having placed me in so low a Sphere, that I have had nothing to do in the great Revolutions of which our Land has lately been the Scene; I must not pretend to judge what has past: But altho I have not been an Actor, I cannot say I have been altogether an unconcern'd Spectator of the great Changes these last Three Months have produced: For what I did not know in the Cause, I thought I might yet lawfully admire in the Effects; which truly have been so miraculous, that 'tis as much the Worlds Wonder as ours: So that if ever People had cause to apply the Words of the Psalmist, Psal. i 8. ver. 23. we certainly may say, This is the Lord's doing, and I'm sure it ought to be marvellous in our Eyes. ${ }^{1}$

So began a pamphlet published in April 1689 as part of the Allegiance Controversy, that series of polemical exchanges on the reciprocal duties of subjects and sovereigns triggered by the forcible expulsion of James II and the elevation to the throne of William III and Mary II. The importance of this controversy and its ideological background have been recognized by historians of

\footnotetext{
Department of History, University of Kansas, I445 Jayhawk Blvd, Lawrence, Kansas, 66o45-759o krpclark@, ku.edu

1 Reflections upon the late great revolution. Written by a lay-hand in the country, for the satisfaction of some neighbours (London: Ric[hard] Chiswell, I689), p. I. References in parentheses in the text are to this pamphlet.
} 
political thought, ${ }^{2}$ but this pamphlet commands a particular significance. It has been influentially attributed to Daniel Defoe $^{3}$ and interpreted as among his most significant early publications: 'This tract is the earliest fully developed expression of Defoe's political theory, which he did not materially alter or develop in later years ' $;{ }^{4}$ a tract in which 'Defoe relied primarily on biblical precedent and what we now consider Lockean arguments for the moral right of revolution' ${ }^{5}$ This account of the inception of Defoe's public career has played an important part in the depiction of him as essentially a popularizer and echoer of Locke, indeed 'a radical Lockean ' $;{ }^{6}$ and for much of the twentieth century, the prevalent understanding of Locke was as a secular thinker.

Although recent scholars of Locke, including Justin Champion, Ian Harris, John Marshall, and John Pocock, have emphasized the centrality to Locke's political thought of his religious views, the significance of this reinterpretation of Locke alone for the taxonomy of early Whiggism as a whole has not yet been generally appreciated. According to one eminent Defoe scholar who accepted the attribution of Reflections, 'The salient features of Defoe's treatise involve his insistence that the relationship between the monarch and his subjects is essentially secular.' That being accepted, Defoe became 'the enthusiastic propagandist, political theorist, and economic prophet for the Glorious Revolution and for its hero, William III ' ${ }^{7}$ Thus the pamphlet shaped scholars' linked understandings of Defoe's subsequent position and of post-Revolution Whig ideology. Reflections has recently been de-attributed as part of a systematic reconsideration of the Defoe canon. ${ }^{8}$ Was it nevertheless by that author?

2 See especially John P. Kenyon, Revolution principles: the politics of party, I689-1720 (Cambridge, I977), chs. I-3; Mark Goldie, 'The Revolution of I689 and the structure of political argument: an essay and an annotated bibliography in pamphlets on the Allegiance Controversy', Bulletin of Research in the Humanities, 83 (1980), pp. 473-564 (esp. list of sources on pp. 526-7); David Martin Jones, Conscience and allegiance in seventeenth-century England: the political significance of oaths and engagements (Rochester, NY, I999); Mark Goldie, ed., The reception of Locke's politics (6 vols., London, I999); Edward Vallance, Revolutionary England and natural covenant: state oaths, Protestantism, and the political nation, 1553-I682 (Woodbridge, 2005); Conal Condren, Argument and authority in early modern England (Cambridge, 2006).

${ }^{3}$ John Robert Moore, Daniel Defoe: citizen of the modern world (Chicago, IL, I958), p. 72; idem, A checklist of the writings of Daniel Defoe (Bloomington, IN, I96o; 2nd edn, Hamden, CT, I97I), no. 6.

${ }^{4}$ F. Bastian, Defoe's early life (London, I98I), p. I40.

5 Paula Backscheider, Daniel Defoe: his life (Baltimore, MD, I989), p. 49.

${ }^{6}$ Ibid., pp. 76, 8I, I6I-3, I68-72; Richard Ashcraft, Revolutionary politics and Locke's Two treatises of government (Princeton, NJ, I986), pp. 222, 565 .

7 Maximillian Novak, Daniel Defoe master of fictions: his life and ideas (Oxford, 200I), pp. 9I, I I2. Novak argues that the more immediate source for Defoe's ideas was his teacher at his Dissenting Academy, Charles Morton, but that this education was still Lockeian, since 'Morton must have met John Locke during his stay at Wadham College in Oxford.' This statement strengthens, without evidence, Novak's earlier argument that 'Morton might well have had some contact with Locke', p. 47 (italics added). Similarly, Novak reads Defoe's account of i688 in The true-born Englishman (I70I) as a description of a 'classic bourgeois revolution' (p. I52).

${ }^{8}$ P. N. Furbank and W. R. Owens, The canonization of Daniel Defoe (London, I988); idem, Defoe deattributions: a critique of F. R. Moore's checklist (London, I994); idem, A critical bibliography of Daniel Defoe (London, I998), pp. 3-4. 
In a learned earlier bibliography of the Allegiance Controversy, Mark Goldie accepted Defoe's authorship, ${ }^{9}$ so that the de-attribution deserves fuller consideration. This article sets out the issues of authorship and reviews the contents of a more than ordinarily important tract at a dramatic moment of crisis and self-justification when people were called on to make explicit what were the grounds, if any, upon which subjects owed obedience to their new prince.

This article also deals with contested questions of method. From the late i6gos to his death in 173I Defoe's œeeuvre was immense, and much of it has been interpreted as a sustained commentary on the events and ideas which the Revolution of 1688 launched. P. N. Furbank and W. R. Owens have recently argued for a radically slimmed-down version of the Defoe canon; ${ }^{10}$ yet their extensive de-attributions have often been resisted, and the full significance of their re-shaping of the canon for Defoe's ideological position has not yet been grasped, either by themselves ${ }^{11}$ or others. This article contributes to that process of appreciation by supporting the de-attribution of a key pamphlet formerly ascribed to Defoe. Moreover, Reflections appeared within a context allegedly populated by four other anonymous pamphlets also attributed to that author, ${ }^{12}$ and these works, taken together, formerly seemed to offer the possibility of a rounded depiction of Defoe's political ideology at the outset of his career. This article examines what has been seen as his chief contribution to the allegiance debate, a sixty-eight-page pamphlet entitled Reflections upon the late great revolution, relates it to these four other publications, de-attributes three of them, and identifies some ideological consequences of this revision of the Defoe canon at a crucial point in the evolution of Whig ideology.

Two cautions should be made at the outset. In I689, Defoe was aged under thirty; with expanding interests in London's Dissenting and trading community, he did not envisage exchanging a merchant's career for that of a professional writer until the late i6gos, when the former path met difficulties and the climate in politics and publishing became friendlier. ${ }^{13}$ Second, recent scholarship on John

9 Goldie noted: 'Defoe launches his career as he means to continue: assaults passive obedience, divine right, sycophancy to tyranny; [he employs] contract and salus populi found in Old Testament and English history': 'Revolution of i689', p. 537, no. 39.

10 See $n .8$ above.

11 P. N. Furbank and W. R. Owens, A political biography of Daniel Defoe (London, 2006).

12 In chronological order, these are: A letter to a dissenter from his friend at the Hague, concerning the Penal Laws and the Test; shewing that the popular plea for liberty of conscience is not concerned in that question ('The Hague', [London], I688); Some short considerations relating to the settling of the government; humbly offer'd to the Lords and Commons of England, now assembled at Westminster (London: 'Printed for N. R.', I689), no licence date given but evidently early in $\mathrm{I} 689$; The advantages of the present settlement, and the great danger of a relapse (London, I689), licensed 4 July; An answer to the late K. Fames's last declaration, dated at St. Germains, April I7, S. N. I 693 (London, I693). The authorship of the last two has been disputed: see Furbank and Owens, Defoe de-attributions, pp. 4, 6-7. Goldie, however, accepted them as Defoe's: 'Allegiance controversy', p. 537 , nos. 40, $4 \mathrm{I}$.

${ }_{13}$ Backscheider, Daniel Defoe, provides a detailed chronicle of the fortunes of Defoe the businessman. The expiration of the Licensing Act in 1695 coupled with the rise of party politics revolutionized England's print culture: J. A. Downie, Robert Harley and the press: propaganda and public opinion in the age of 
Locke implicitly distances him from Defoe's thought. It is now evident that Locke's Two treatises of government (I689) later acquired a prominence beyond their importance in the Allegiance Controversy during which they were first published. The connection between Defoe and Locke was first made during the early eighteenth century by the Anglican divine and Nonjuror, Charles Leslie, who linked the two Whig apologists together in an attempt to discredit both. Leslie's campaign served to make Locke's Two treatises more central to twentiethcentury scholarship than they were to eighteenth-century political argument. ${ }^{14}$ This de-centring of Locke implies a re-centring of Defoe the Nonconformist within early Whiggism, but this implication has not yet received wider acknowledgement.

The influence of other writers on Defoe's thought has been obscured by the 'card trick of history' which attributes to Locke an influence which he acquired only later. ${ }^{15}$ Despite Defoe's participation in Monmouth's rebellion and in Charles Mordaunt's city regiment in I689, there is no conclusive evidence linking Defoe's thought with the populism of the exclusionists or republicans. ${ }^{16}$ I argue elsewhere $^{17}$ that Defoe was a spokesman for theologically orthodox Dissent, specifically Presbyterianism. He was neither a republican nor a Deist: his aim was to discredit not the institution of monarchy itself, but the theory of divine right and those who employed it in defence of James II and the exiled Stuarts. ${ }^{18}$ Throughout his career, Defoe often denounced the republican and Deistic beliefs of the heterodox. In I706, for example, he was insistent that 'a Monarchy according to the present Constitution limited by Parliament, and dependent upon Law, is not only the best Government in the world; but also the best for this Nation in particular'; he urged fellow Dissenters to reject John Toland's call that they should declare for 'an Universal Toleration of all Opinions merely Religious' since Scripture enjoined the church not to tolerate doctrines 'Heretical and

Swift and Defoe (Cambridge, 1979);J. G. A. Pocock, The Machiavellian moment: Florentine political thought and the Atlantic republican tradition (Princeton, NJ, 1975), pp. 423-505.

${ }^{14}$ John Dunn, 'The politics of Locke in England and America in the eighteenth century', in J. W. Yolton, ed., Fohn Locke: problems and perspectives (Cambridge, I969), pp. 45-80; Martyn P. Thompson, 'The reception of Locke's Two treatises of government, I69o-1705', Political Studies, 24 (1976), pp. I84-9I; James Moore, 'Theological politics: a study of the reception of Locke's Two treatises of government in England and Scotland in the early eighteenth century', in Martyn P. Thompson, ed., fohn Locke und/and Immanuel Kant: historische Rezeption und gegenwärtige Relevanz (Berlin, I99I), pp. 62-82.

${ }^{15}$ Conal Condren, George Lawson's Politica and the English revolution (Cambridge, I989), pp. I66-9. Condren points out similarities between arguments in George Lawson's Politica sacra Eै civilis (I660; reprinted I689) and Defoe's The original power of the collective body of the people of England (I7oI), for which see below.

${ }^{16}$ For their 'congregating around the deist John Toland' and their republicanism, see Mark Goldie, 'The roots of true Whiggism, I688-94', History of Political Thought, I (r980), pp. 195-236, at pp. $196-7$.

${ }_{17}$ Katherine Clark, Daniel Defoe: the whole frame of nature, time and providence (London, 2007).

${ }^{18}$ Defoe claimed to have angered Whig friends by writing a pamphlet denouncing the Turks for their conduct during their siege of Vienna in ${ }^{6} 68_{3}$ (so placing the safety of Christendom before the defeat of a Catholic alliance between the Empire and France), but no text has been discovered: Defoe, An appeal to honour and justice (London, I715), p. 223. 
Abominable'. ${ }^{19}$ The political views of the Socinian Locke and the Trinitarian Defoe overlapped at several points, but there were differences; what is at issue is the political stance of theologically orthodox Dissent, its similarities to, and differences from, Anglican Whiggism.

Although Locke and Defoe both gave pride of place to reason and the law of nature, Defoe's key work Fure divino (1706) lacks the ideas of the Two treatises that were specific to Locke alone: the individual's right to execute justice in the state of nature; money as proof of tacit consent to private property; and the labour theory of value. ${ }^{20}$ A leading authority on the Allegiance Controversy formerly categorized Defoe as a 'radical Whig [who] used a natural law case for resistance or a right of deposition' ${ }^{21}$ but this is too simple: although Defoe invoked natural law, the essentially Scriptural basis of his thought emerges from a reconsideration of him as a Trinitarian Dissenter. ${ }^{22}$ Neither Defoe nor the pamphlet examined here can be explained so easily: Reflections appeared several months before Locke's Two treatises and employed almost every defence of the Revolution except a natural law one. Natural law was prominent in Locke's work, meaning principally what could be inferred by reason in an undated state of nature; in Defoe's, the law of nature was more clearly a synonym for divine command, and had only one obvious application: 'Nature Commands ... Self-Preservation'. Crucially, Defoe did not use Locke's theoretical construct of a 'state of nature'. For Defoe, 'Government is an Appendix of Nature, one of the first rational Dictates to Man from his Understanding; 'tis formed in the Soul, and therefore of Divine Original. ${ }^{23}$ Locke used the idea of a state of nature to argue the opposite.

If Locke has been reinterpreted, Defoe too needs reconsideration. It was once conventional to claim (especially in the light of the distended Defoe canon then accepted) that his journalistic skills often led him to argue on both sides of a question. Recently, it has become similarly conventional to assert that Defoe adopted a series of different identities, re-inventing himself in shifting circumstances. This article does not argue for an unchanging Defoe (indeed it points to the importance of his reaction to the High Church resurgence of c. I706); it does, however, proceed from the contention that a revised canon and a new appreciation of Defoe's lasting commitment to Trinitarian Nonconformity allow the degree of his consistency over time to be better discerned. Yet Defoe's fuller account of his views on political theory in fure divino (I706) was part of this more consistent stance, so that it would be unsubstantiated to argue that he had merely changed his mind since I689. ${ }^{24}$

19 Daniel Defoe] Fure divino: a satyr. In twelve books. By the author of the true-born-Englishman (London: no printer, I706), pp. iv, xix-xx. Defoe listed the doctrinal points on which 'all Orthodox Christians agree'; those who denied those doctrines 'ought not to be suffered, that is, Tolerated', p. xxi.

20 Clark, Daniel Defoe, p. 55.

21 Goldie, 'Revolution of I689', p. 508. In the bibliography, however, Goldie emphasizes that arguments in Reflections are historically based.

${ }^{23}$ [Defoe], The Review, Io Sept. I706; cf. I5 Aug. I705.

${ }_{22}$ Clark, Daniel Defoe, passim.

${ }^{24}$ Clark, Daniel Defoe, passim. 
A reconsideration of Defoe, then, depends in part on the de-attribution to him of Reflections upon the late great revolution. First, circumstantial evidence tells against his authorship. It is noteworthy that he did not reprint it in the 'authorized' collection of his writings, A true collection of the writings of the author of the true born Englishman. Corrected by himself (London, I703), nor in the second edition, 'Corrected and enlarg'd by himself' (London, I705), although this collection included many of Defoe's tracts on politics and religion, and although Reflections, as a serious and weighty piece, would have comfortably deserved a place. Had space dictated the exclusion of Reflections from his first collection, Defoe might have included it in A second volume of the writings of the author of the true-born Englishman (London, I705), but he did not do so. Nor did Reflections appear in John How's pirated version of Defoe's collection, A collection of the writings of the true-born Englishman, although this volume included two anonymous pieces that Furbank and Owens describe as 'probably' by Defoe. ${ }^{25}$

It is important contemporary evidence that Reflections was indeed included in the first volume of another three-volume contemporary anthology, published in I703-5, but there listed as 'By Mr. Eyres', the only pamphlet attributed in this collection to that author. ${ }^{26}$ (J. R. Moore noticed this attribution but dismissed it as 'Mistakenly attributed' without further enquiry. ${ }^{27}$ ) The attributions in this work were evidently careful; A memorial from the English Protestants was only listed as 'Said to be written by Major Wildman'; many tracts carried no author's name; another, The advantages of the present settlement, featured as 'By P. A. D.D.', that is, Pierre Allix, an attribution which conforms with recent research (see below). The identity of 'Mr. Eyres' is not yet clear. One possibility is the Whig lawyer Robert Eyre (I666-I735), from I698 an MP, a barrister in I69o. But the pamphlet's open defence of episcopacy, its deep Scriptural learning, and its profession to be written from the country, might point to a clergyman in the diocese of Winchester, Robert Eyre (I656/7-I722), in I693 a Fellow of Winchester College, and Eyre's prose is strikingly similar to that of the Reflections. ${ }^{28}$

25 Furbank and Owens, Critical bibliography, p. 4.

${ }^{26}$ A collection of state tracts, publish'd on occasion of the late revolution in I688. And during the reign of king William III (3 vols., London, I703-5), I, list of contents.

${ }^{27}$ Moore, $A$ checklist of the writings of Daniel Defoe (I97I), no. 6.

${ }^{28}$ Robert Eyre published under his own name: A discourse concerning the nature and satisfaction of a good and inoffensive conscience. In a sermon preach'd in the cathedral church of Winchester, at the assizes held there April II. I693 (London, I693); The sinner a traitor to his king and country. In a sermon [on I Sam. I2.25] preach'd in the cathedral-church of Winchester, at the assizes held there, Fuly 24. I70o (London, I700), in which he praised William III as 'our Great Deliverer, and the happy Instrument of his Providence', p. I8, and expounded again the Scriptural text that was prominent in the Reflections; and A sermon preach'd before the honourable House of Commons, at St. Margaret's Westminster, on Friday Jan 30. I707/8 (London, I708), in which he showed knowledge of Grotius, p. 2. Eyre matriculated at New College, Oxford, in i676, became a fellow of the college, and took the degree of DD in 1697 ; in I70o he became a canon of Winchester Cathedral: Anthony à Wood, Athenae Oxoniensis, ed. Philip Bliss (4 vols., London, I820), IV, p. $55^{8}$. Another possible candidate, William Eyre, author of Vindiciae justificationis gratuitae (2nd edn, London, 
Nor did Defoe include in his two collected volumes of $1703^{-} 5$ any of the other four pamphlets from the time of the Revolution that have been attributed to him. Only the first of these seems to be genuinely Defoe's, and this addressed the issues of religious toleration that had preoccupied him before the Revolution, rather than the political events of James's deposition and its momentous, but complex, theoretical consequences. The absence of the first pamphlet, $A$ letter to a dissenter from his friend at the Hague, from Defoe's own collected volumes may not be strong evidence against his authorship, since Defoe later wrote of his having, in the reign of James II, opposed 'the taking off the Penal Laws and Test'. ${ }^{29}$ $A$ letter to a dissenter was not happily reprintable in later years: $:^{30}$ it had written of 'Liberty of Conscience' as a 'great Pretence'; it had recommended the acceptance of indulgence under James II, leaving the Penal Laws and Test in place as important barriers against the pressing threat of popery. 'Liberty of Conscience', it had argued, 'may be had without the repeal of the Test and Penal Laws. ${ }^{, 31}$ After the Revolution, this position became acutely inconvenient, and the threat of Catholicism greatly receded. If Defoe were the author, as its prose style suggests, the wholly changed political landscape may have been a reason for his not reprinting this early work, which had upset his co-religionists. Yet $A$ letter to a dissenter may establish connections with Defoe's preoccupations in his Fure divino (I706): the work of I688 was preoccupied with questions of religious toleration; saw the chief danger not as monarchy, but as Catholicism; and ignored potentially secular devices such as contract and the state of nature. Such connections, if correctly identified, raise the question of how far resistance theory was a common possession of English Nonconformists before I688, and how far it was characteristic of smaller groups like freethinkers.

The second pamphlet, Some short considerations relating to the settling of the government, argued that 'The King has forfeited his Power several Ways', including desertion. ${ }^{32}$ This tract was attributed to Defoe on the grounds that part of the argument was repeated in A compleat history of the late REVOLUTION (London, I69I), also once attributed to him. ${ }^{33}$ But since the Compleat history was explicitly claimed as his own by Guy Miege, a native of Lausanne and presumably a Calvinist, ${ }^{\mathbf{3 4}}$

I695), was evidently a Dissenter, and so unlikely as the author of a pamphlet, Reflections, which commended episcopacy.

${ }^{29}$ Furbank and Owens, Critical bibliography, pp. 7-8; John Robert Moore, 'Defoe's "lost" letter to a Dissenter', Huntington Library Quarterly, I4 (I95I), pp. 299-306.

${ }^{30}$ It was reprinted in Fourteen papers (London, I689), but there is no evidence that this was Defoe's compilation. The volume is a reprint of fourteen pamphlets, by various hands, issued without any editorial introduction and licensed on 2I Dec. I688, in the heat of the revolution. It was probably a money-making venture by its publisher, Richard Baldwin.

31 'What can the Repeal of the Penal Laws and Test do for you which the King's Declaration hath not done?': A letter to a Dissenter, pp. I-2.

32 Some short considerations relating to the settling of the government, p. 5 .

${ }^{33}$ Bastian, Defoe's early life, p. I38.

34 Utrum horum? Tyranny, or liberty. Oppression, or moderation ... By G[uy] M[iege $]$ (London, I705), p. 30. 
there are some grounds, albeit not decisive, for attributing Some short considerations to Miege also; there are no grounds for ascribing it to Defoe, whose prose style it does not resemble.

The third pamphlet, The advantages of the present settlement, and the great danger of a relapse, argued that James II's misdeeds 'perfectly dissolve the Government to our hands'; in such a case, 'what can reasonably be expected from them [the people] by the Laws of God, of Nature, and Self-preservation, the first and great Principle of Nature, but that they should look out for better terms where they may have them?' (p. I9). It has been plausibly attributed to Pierre Allix (I64I-I7I7), ${ }^{35}$ a Huguenot minister and refugee in England after the revocation of the Edict of Nantes, reordained in the Church of England, and well connected in London. After the expulsion of James II, Allix produced a stream of virulent anti-Catholic pamphlets in 1689 , which all appeared without his name on the title page, but were mostly published by Richard Chiswell in St Paul's Churchyard, who had also published The advantages. ${ }^{36}$ There are no better reasons for attributing this pamphlet to Defoe.

The fourth pamphlet, An answer to the late K. James's last declaration, argued in radical Whig terms that the nation had 'withdrawn their Allegiance' from James II ' and confer'd it upon another' (p. 3). Yet the tract has been plausibly attributed to James Welwood (I652-I727). Born the son of a Scots Presbyterian minister ejected from his living in ${ }^{6} 66_{3}$ for rejecting episcopacy, Welwood's family was implicated in covenanting. He was himself under suspicion and forced to flee Scotland after the murder of Archbishop Sharp in I679. Supporting himself by medicine, Welwood was drawn to London in 1689 where his anti-Stuart writings brought him the favour of Gilbert Burnet and the post of an extra-physician to William and Mary, as well as a succession of government medical appointments. ${ }^{37}$ In return, he was an active Whig author in the I6gos, latterly using the publisher Richard Baldwin in Warwick Lane who also published An answer; in particular, Welwood was responsible for the journal Mercurius reformatus which appeared three times a week in the early i6gos and presented a committed version of the Williamite cause. ${ }^{38}$ There is no evidence to prefer Defoe as the author of An answer.

35 Vivienne Larminie, 'Pierre Allix', Oxford dictionary of national biography, does not notice the attribution to him of The advantages; Furbank and Owens, Defoe de-attributions, p. 4 .

36 The following were all printed by Richard Chiswell and have been attributed to Pierre Allix: Some considerations touching succession and allegiance (London, I689), licensed 9 Apr.; An examination of the scruples of those who refuse to take the oath of allegiance. By a divine of the Church of England (London, I689), licensed I6 Apr.; An account of the private league betwixt the late king Fames the second, and the French king (London, I689), licensed 2 May; A letter from a French lawyer to an English gentleman, upon the present revolution (London, I689), licensed 27 May; Reflections upon the opinions of some modern divines, concerning the nature of government in general, and that of England in particular (London, I689), licensed 29 June.

37 Elizabeth Lane Furdell, 'James Welwood', Oxford dictionary of national biography; Furbank and Owens, Defoe de-attributions, pp. 6-7.

38 The following have all been attributed to James Welwood: Reasons why the parliament of Scotland cannot comply with the late $k$. Fames's proclamation (London: Dorman Newman, I689); $A$ vindication of the present great revolution in England; in five letters pass'd betwixt Fames Welwood and fohn Marsh (London: 
These de-attributions of more extreme writings, none probably by English Whigs, reduce the Defoe canon at the time of the Revolution considerably: only $A$ letter to a Dissenter (I688) and A new discovery of an old intreague (I69I), the latter acknowledged by Defoe's inclusion of it in A second volume of the writings (1705), survive before the torrent of Defoe's publications unquestionably began with An essay upon projects, advertised on I9-2I January I697. ${ }^{39}$ From I689 until his spectacular bankruptcy in October I692, Defoe was evidently preoccupied with rescuing his business affairs. ${ }^{40}$ The circumstantial case for attributing to him Reflections upon the late great revolution emerges as a weak one.

Defoe's political stance was indeed distinct; but it was provoked into theoretical expression less by prior comments on monarchy or resistance than by a challenge to the Trinitarianism that his Presbyterian denomination shared with churchmen. ${ }^{41}$ Between I688 and I70o, his writings on the nature of kingship were conspicuous by their absence; not until fure divino (I706) did he write at length on that theme..$^{42}$ By comparison, and with a conservative eye toward attribution, between I698 and I707 Defoe wrote over twenty pieces on the questions of Dissent and occasional conformity; he contributed close to forty works to the debate over union with Scotland. Nor was Defoe quite the man of affairs that he later presented himself as having been. An older generation of scholars, working with the extended Defoe canon, persuaded themselves of 'Defoe's friendship with the king throughout the reign' ${ }^{43}$ Yet there are reasons for thinking that Defoe later retrospectively exaggerated his closeness to William III in I jor and to the dynastic issues that had preoccupied that monarch and many of his supporters. ${ }^{44}$ If Defoe enjoyed no such privileged access to the centre of events even by I70I, his attention to dynastic matters in I689 may have been more distant.

Defoe, then, did not enter elsewhere into the complexities of the Allegiance Controversy in I689-9I. His earliest pronouncements on the issues at stake in the Revolution date from I70r and $\mathrm{I}_{70} 3{ }^{45}$ and insisted, instead, in the more generalized terms that would come naturally to a Dissenter, that by 'The Laws of Nature'

R. Taylor, I689); An answer to the late king James's declaration to all his pretended subjects in the kingdom of England, dated at Dublin-Castle, May 8. I689 (London: Dorman Newman, I689; repr. I693); An answer to the vindication of the letter from a person of quality in the north (London, s.n., I69o); A modest enquiry into the causes of the present disasters in England (London: Richard Baldwin, I69o); Mercurius reformatus: or, the new observator: containing reflexions upon the most remarkable events, falling out from time to time in Europe, and more particularly England (London, I689-?93: initially printed for Dorman Newman, but after vol. 4 no. I by Richard Baldwin); An appendix to Mercurius reformatus or the new observator (London: Richard Baldwin, I692).

40 Backscheider, Daniel Defoe, pp. 50-6r.

${ }^{41}$ Clark, Daniel Defoe, passim.

42 Furbank and Owens, Critical bibliography, nos. I-I6.

${ }^{43}$ Moore, Daniel Defoe, pp. 70-3; Bastian, Defoe's early life, pp. 7, 225.

44 P. N. Furbank and W. R. Owens, 'Defoe and King William: a sceptical enquiry', Review of English Studies, 52 (200I), pp. 227-32; J. A. Downie, 'Daniel Defoe: King William's pamphleteer?', Eighteenth-Century Life, I2 (1988), pp. I05-17.

45 The original power of the collective body of the people of England, examined and asserted (London, I702 [for I70I]), partly reprinted in Some remarks on the first chapter in Dr. Davenant's essays (London, I704 [for I703]). 
the 'Collective Body of the People' were 'the Fountain of Original Right'. In early I689, because 'the King was gone' (by implication avoiding the question of deposition), 'all [authority] retreated to the great Original Power of the People'. They exercised it in the Revolution via the Convention Parliament, 'which in English I take to mean a meeting of the Collective Body'. William III, therefore, was presented with 'the Conditions of his Government' and 'Accepts the Crown on those Terms'. But this was not 'a Mob Doctrine', insisted Defoe, for the People were 'Negatively, not all the Inhabitants, but positively all the Freeholders' ${ }^{46}$

It is likely that the Nonconformist position hardened over time, from a widespread willingness before 1688 to reach some sort of accommodation with James II to Defoe's agitated reaction in I706, the day of a resurgent High Church party, occasional conformity bills and Charles Leslie, that 'the World seem'd to be going mad a second Time with the Error of Passive Obedience and Non-Resistance'. Defoe now responded with a more emphatic assertion of a right of deposition than was present in the writings of all but the Commonwealthmen before i688. In I7o6 Defoe wrote openly of 'Dethroning the Late King' in the Revolution; he argued that when kings 'break the Laws ... they may be opposed and resisted by Force'; the Church of England itself 'has not only deposed the King that pretended to this empty Title' by divine right 'but has deposed the very Doctrine itself', even though James II 'did Abdicate and leave the Kingdom'. On successive pages, Defoe wrote of 'King James's Abdication' and 'his Deposing': authors were not as logically consistent as historians would wish. Defoe's emphasis in I706 was clear: 'The Sum of all is this; all Nations determine, That Kings who invade their Peoples Liberties ... MAY Be Resisted ' ${ }^{47}$ Defoe still saw this as a moderate position; but it was one whose application had been developed by resurgent High Churchmanship.

\section{I I}

If circumstantial evidence tells against his authorship, the text of Reflections also provides evidence against an attribution to Defoe. This demonstration is not easy, however, since, on first reading, the contents seem to echo Defoe's supposed views. Yet it will be argued here that they represented an Anglican Whig position far from synonymous with a Nonconformist one.

The target of Reflections was twofold: 'First, That Monarchy is Fure Divino'; second, that subjects commanded by a king contrary to law were obliged in conscience to 'yield Obedience either Active or Passive'. The first of the pamphlet's three parts summarized its attack on divine right monarchy (pp. 6-7):

First, That Monarchy was not at the first Instituted by God Almighty: Secondly, That after Monarchy was permitted and established among the Jews, the People did make and set up

\footnotetext{
46 Some remarks, pp. I3, 20-3. This pamphlet was, in the spurious context denied here, interpreted by Bastian, Defoe's early life, p. I36, as a radical Whig one. In its proper context, it becomes a moderate Whig position.

${ }^{47}$ [Defoe], Fure divino, pp. i, iii, vi-vii, x-xi, xiv, Bk II, p. 2.
} 
their Kings; and Thirdly, That those Kings which were named and appointed by God himself had not an absolute Power, but were under Conditions and Covenants.

These seem familiar points, but the differences between Reflections and Defoe's views will become clear.

Part I of Reflections (pp. 6ff) attempted to demolish divine right by basing its arguments on the Old Testament, with particular emphasis on the history of the kings of Israel and Judah. After surveying the origins of monarchy and its 'Limited and Conditional' legacy among the Jews, the author proceeded to dismantle the doctrine of passive obedience, the second main 'Foundation Stone' of opposition to the Revolution (pp. 6, 34). In Part II (pp. 34ff) the author concluded that "tis from the Statute-Book, not the Bible, that we must judge of the Power [of] our Kings ... and the measures of our Subjection'; the second section of the essay therefore shifted its focus from the history of the Near East to that of England (p. 35). The third and final part (pp. 52ff) sought to answer possible objections. The pamphlet concluded as it began, with exhortation to accept and 'bless God for his wonderful Deliverance' (p. 68). Its leitmotiv, then, was Providence, and this offers a possible clue: Defoe, too, was preoccupied by Providence where providential arguments were not common in the pamphlet controversy. ${ }^{48}$

Yet this is not conclusive evidence of his authorship, for Anglican authors also employed providential arguments. Providential rhetoric in this period was once dismissed as merely a 'devotional platitude' that did not 'change men's minds', but recent scholarship has rehabilitated that language. ${ }^{49}$ Such themes were far from a monopoly of Dissenters. Churchmen also relied on Scripture history as one arena in which Providence was expressed. Reflections was based on a detailed examination of biblical history to adduce the precise balance between divine prescription and human agency in the institution of kingship (p. 6). Only later did the author supplement such arguments with evidence from English history. Attributing Reflections to Defoe, John Robert Moore disparaged the pamphlet as 'old fashioned', preoccupied with Scriptural events. ${ }^{\mathbf{5 0}}$ Yet reason and history, including Scripture history, were not the antitheses in late seventeenth-century thought that they were later to become..$^{\mathbf{5 1}}$

48 Goldie, 'Revolution of i689', p. 489.

49 Kenyon, Revolution principles, p. 25. Subsequent scholarship has recovered the Providential dimension of early modern thinking, e.g. John Spurr, " Virtue, religion and government": the Anglican uses of providence', in Tim Harris, Paul Seaward, and Mark Goldie, eds., The politics of religion in Restoration England (Oxford, I990), pp. 29-47; Michael Winship, Seers of God: Puritan providentialism in the Restoration and early Enlightenment (Baltimore, MD, I996); Alexandra Walsham, Providence in early modern England (Oxford, I999); Warren Johnston, 'The patience of the saints, the Apocalypse, and moderate nonconformity in Restoration England', Canadian Journal of History, 38 (2003), pp. 505-20; idem, 'Revelation and the Revolution of I688-I689', Historical foumal, 48 (2005), pp. 35I-89.

50 Moore, Daniel Defoe, p. 72.

51 Martyn P. Thompson, 'A note on "reason" and "history" in late seventeenth-century political thought', Political Theory, 4 (I976), p. 497. 
Relying on Scripture history, Dissenters and churchmen shared a premise about evidence. Confident that 'God's Word' was 'the surest way' to know His will, Reflections asserted that it was not 'unreasonable' to expect Scripture to provide explicit proof of monarchy's asserted jure divino authority. Such a power must have been either 'immediately Instituted' by God or obedience to it 'positively Commanded' by Him at some later point in time (p. 7). Both the Jewish and Christian churches met these two criteria, as Scriptural accounts of the Passover and Last Supper verified. Yet

although I cannot say I rank Kings in that Classis, yet I do own an Order of Men to be fure Divino, and that is the Bishops; for that of St. Foh. 17.18. As thou hast sent me into the World, even so send I them into the World, seems to me so powerful, and so full a Commission, that I dare not reject it.

This was followed by a challenge to 'our Monarchical Men' to produce 'a Text of Scripture, wherein our Saviour does as fully make over his Regal Authority to Kings, as he does there his Prophetical to the Apostles'. The author clinched this point with a hypothetical case: Anglican missionaries proselytizing in 'the Indies' would be obliged by reason and conscience to institute episcopacy, but English conquerors would not have to model their colony as a monarchy (p. 8). Such cannot have been the view of Defoe, committed to the view that a Presbyterian church polity, not an episcopalian one, was deducible from God's command. As he expressed it in I7or, the Church of England could not be the 'best Guide'

I. On account of the Episcopal Hierarchy, Prelatical Ordination, and Superintendancy.

2. On account of their imposing things owned to be indifferent [to salvation] as terms of Communion.

3. On account of their imposing things own'd to be otherwise indifferent, as made necessary by the Command of the Civil Magistrate..$^{52}$

Champions of Defoe's authorship of Reflections have suggested that the pamphlet's comments on episcopal authority were part of a 'deliberate ruse' on his part to contrive 'a traditionally conservative Anglican voice' to appeal to a wider audience. ${ }^{53}$ Such an argument is unsupported by evidence.

If jure divino kingship needed historical demonstration, the author of Reflections laboured to prove a negative for the centuries after Adam and before the rule of Saul, David, and Solomon. For over three millennia, the Bible showed no

${ }_{52}$ [Defoe], A letter to Mr. How (London, I7oI), reprinted in [Defoe], A true collection of the writings of the author of the true born English-man. Corrected by himself(London, I703), p. 330. For the earlier history of Presbyterian claims of divine right for their form of ecclesiastical polity, see Jeremy Goring, 'Introduction', and C. G. Bolam and Jeremy Goring, 'English Presbyterian beginnings', in C. G. Bolam et al., English Presbyterians (London, I968), pp. 20, 29-72; Peter Lake, 'Presbyterianism, the idea of a national church and the argument from divine right', in Peter Lake and Maria Dowling, eds., Protestantism and the national church in sixteenth-century England (London, 1987), pp. 193-224.

${ }^{53}$ Manuel Schonhorn, Defoe's politics: parliament, power, kingship and Daniel Defoe (Cambridge, 199I), pp. 22-3 (in other places, Schonhorn's argument points as much to Defoe's Presbyterian identity as it does to any Anglican persona); Bastian, Defoe's early life, p. I40. 
evidence of monarchy's divine inception. Nor was its advent among the Hebrews the result of God's command but rather, as the first book of Samuel stated, the result of God's acquiescence in the people's desire for one-a desire which brought 'very severe and bitter Reproofs' from that same prophet and a later confession from the people that 'We have added to all our sins this evil in asking us a King' (pp. 9-Io). Defoe argued similarly, but citing Pufendorf: 'even at the time of the Deluge, there was no Magistracy, or any Civil Constitution '.54

Reflections continued that if the descendants of Abraham had lived without a king until the reign of Saul, neighbouring nations had shared a different fate. In the second century after the Flood, Nimrod, the first king 'we find mentioned in Holy Writ', founded a kingdom 'by Force and Violence'. In Nimrod's aggression, the author saw the origins of an important historical dynamic: 'Nimrod carrying on his Kingdom by the same means he began it, made it necessary for some that were his Neighbours, to set themselves up Kings, that they might be the better able to oppose him' (pp. Io-II). Monarchies were not sacred in origin. They arose in conquest and urbanization, and were not the political expression of the natural authority of fathers over their families. Anglican and Nonconformist agreed: Defoe took a similar view of the origins of Nimrodic kingship, citing Sir Walter Raleigh, but was even more concerned to condemn Nimrod for idolatry. Nimrod had been idolized in his kingdom and transmuted into the god Belus or Baal, and so identified as a euhemeristic precursor of Louis XIV. ${ }^{\mathbf{5 5}}$

The conviction that the origins of kingship lay not in God's grant to man of dominion over the earth but in Nimrod's arrogation of dominion over other men enabled the author of Reflections to explain monarchy's expansion. 'Pride and Ambition' had led some men to extend their power through usurpation and conquest, thereby provoking others to envy and imitation (p. II). The desire for self-preservation stimulated others to seek divine guidance and to reorganize their society under a warrior-king. Military leadership and the ability to preserve the nation from foreign domination became a sine qua non of kingship. Here the Reflections paralleled Defoe's abiding esteem for the figure of the warriorking - conventionally ignored or considered a personality trait and more recently depicted as a search for 'the soldier-redeemer ${ }^{\mathbf{5 6}}$ - which for Defoe was rooted in historical analysis, rather than in emotion or apocalyptic royalism.

54 [Defoe], Fure divino, Bk II, p. 4; Samuel Puffendorf [sic], An introduction to the history of the principal kingdoms and states of Europe [trans. Jodocus Crull] (London, I695).

${ }_{55}$ [Defoe], Fure divino, Bk I, pp. 3 (Raleigh), 5, Bk II, p. 20; [Defoe], The political history of the devil (London, I726), pp. I46-57.

56 For Defoe's search for a Protestant hero, see Schonhorn, Defoe's politics, p. 4. Defoe's admiration for warrior kings has often been ignored by those who wish to depict him as a radical Whig or republican: Richard Ashcraft and M. M. Goldsmith, 'Locke, revolution principles, and the formation of Whig ideology', Historical foumal, 26 (I983), pp. 773-80o; Laurence Dickey, 'Power, commerce and natural law in Daniel Defoe's political writings, I698-1707', in John Robertson, ed., A union for empire: political thought and the Union of I707 (Cambridge, I995); Peter Earle, The world of Defoe (London, I976). 
In Reflections, Nimrod's aggression laid the foundations for a system of oriental despotism to which the Hebrew nation would eventually respond by importuning their God for the protection which kings afforded their peoples. Whatever the case with Nimrod, the Jews acquired their kings differently. A key event in Scripture was the installation of Saul as the first king of Israel. According to Reflections, 'God did comply with the Peoples Request', although reluctantly, and God 'appointed' Saul as king, who subsequently was 'solemnly Anointed by Samuel, I Sam. Iо. I. chosen by Lot at the Assembly of the Tribes at Mizpeh, ver. 2 I. and declared King, ver. 24' (p. I2). Given its ambiguous blend of divine and popular roles, the account of Saul's election and kingship in the Book of Samuel was subject to a spectrum of interpretation from extreme royalism to republicanism. Its Scriptural importance and its ambiguity made it a locus classicus of English constitutional debate.$^{57}$ Reflections thus gave God a role in the elevation of Saul, but Defoe was to be decidedly more dismissive: 'In all the Moral Laws, in all the Institutions of Providence read of in the early History of the World, Heaven was observ'd never to direct them [the people] in Matters of Government, as a thing left wholly to their own Choice.' In the case of Saul, 'Heaven the Design abhorr'd,/And left his High Dislike upon Record.' True, 'Saul was King by Heaven's immediate Hand,/But 'twas in Fudgment to afflict the Land', since Saul was 'a Boy' and militarily incompetent. ${ }^{\mathbf{5 8}}$ This was no happy precedent.

Defoe would later disagree that any kings had received a favourable and direct divine commission. His fure divino, Book I, presented a picture of monarchy originating when patriarchs, heads of families, joined together for mutual defence, so that, in Book v, property was 'prov'd the true and only Original of Power'. Nimrod's usurpation of absolute power came later. Consequently kings 'have no Powers immediately Deputed from Heaven superior and unsubjected to the Good of those they govern'; government was, rather, 'prescrib'd by Laws, Compacts and Agreements' when patriarchs chose one of their number as 'Duke or Captain; and after ... King', ${ }^{59}$

If a churchman, it was understandable that the author of Reflections did not wish to give a systematic account of resistance theory. Indeed, his comment that most kings of Israel who came to grief were 'rejected, not for ... Treason, but ... Idolatry' (pp. I8-I9) made resistance even more problematic. True, unjust kings might lose their thrones, but this was principally God's work: 'God may, and oftentimes does take the Forfeiture, as we see here both in the Case of David and Feroboam.

\footnotetext{
57 Schonhorn, Defoe's politics, p. II2: Schonhorn sees Saul as the key to understanding Defoe's politics. On the significance of ambiguity in political argument, see Condren, Lawson's Politica, pp. 83, I I4-I5, I93; 'what matters here is how Defoe's argument illustrates the differing patterns of ideas that can come from a common terminological legacy', p. I67.

58 [Defoe], Fure divino, Bk II, pp. 23-4, 27.

59 Ibid., pp. 2, 5, I6. This was Defoe's basic position, although somewhat modified in his account of Saul.
} 
But when, and how far those Forfeitures are to be taken, ought to be left to that Almighty Wisdom and Providence, that turns every thing to good' (p. I5). The author was reluctant to explore that theme. A particular problem was Amaziah, who incurred divine wrath after he returned from military campaign worshipping foreign gods. Ignoring the admonitions of the prophet sent by the Lord to rebuke him, he soon suffered military defeat, was deposed and murdered by his subjects (p. 21). Although Amaziah was deposed and killed by the people, 'that his turning away from following the Lord, did give his Subjects Authority to depose, and to kill him, is that which I should be very loth to affirm'. Aware that readers might think this a justification for the regicide of Charles I, 'the best of Kings, and of Men', the author immediately distanced himself from the idea, and recorded his astonishment: 'I can never read that Story [of Amaziah] but with wonder, to find, that the People are neither upbraided with it, nor punish't for it' (pp. 2I-2). But he had no real solution to the problem.

Such were the lessons of Scripture history in Part I of Reflections. Part II applied them to English history to refute 'the Doctrines of Non-resistance and Passive Obedience' (p. 34), but the application was difficult. Since English kings were not immediately set up by God, Reflections had to offer a contractual account of their origins which echoed the origins of Hebrew kings (pp. 27-9, 3I). Part II countered a favourite shibboleth of absolutists: Christ's command to 'Render unto Cesar', the author argued, 'does not pretend to tell us what is Cesar's due, because no general Rule could be given in that Case, the Rights of Kings and People varying almost in every Country' (pp. 34-5). He extolled the virtues of English government within a familiar taxonomy. Monarchy, 'which, generally speaking, is the best Government in the World', was elective or hereditary, absolute or limited. England enjoyed a hereditary and limited monarchy which the author took to be 'the happiest Constitution under the Heavens ... [and] next [to] being born within the Pale of the true Church ... one of the greatest Privileges any ones Birth can entitle him to' (pp. 35-6). Again, church membership came first for the author, as it would not have done for Defoe.

Furthermore, the one, the few, and the many formed 'a kind of Trinity' which like that of 'our Faith' was also a 'Unity: for their Power is so equal in the Great Point of Legislature, that one cannot properly say, that one is greater, or less than another... [as] the Consent of the whole Three is necessary both to the making and abrogating a Law'. Reflections conceded the king held the 'Executative [sic] Part of the Power' but this was by 'Consent of the other Two ... and under such Limitations, that it cannot properly be call'd the Supreme Power'. Besides, 'the Legislative Power is in all nations esteemed the Supreme, and ours being so divided, it seems to be a little improper to call any One of the Three the Supreme Power' (p. 37). Seventeenth-century political thinkers debated whether there had to be one original and constitutive power which was necessarily 'supreme' in the sense that it could not logically beget a sovereign greater than itself. Though denied by Grotius, the idea was a major tenet of Lawson's Politica sacra E civilis, an important source for allegiance 
controversialists. ${ }^{60}$ Defoe came to rely on Lawson's interpretation in later years but, perhaps because he wished to emphasize the notion of conjoined, rather than popular, sovereignty, the author of Reflections seemed less concerned about the idea.

Like the Hebrews, ancient Britons agreed to submit to a single ruler to preserve their own security and prosperity from violence and instability. Consequently, 'the same Terms and Conditions were agreed to, and confirmed by his Successors' (pp. 40-I). The author included the standard Whig argument that William I had 'wa[i]ve[d] his Title of Conquerour' in favour of a title by law; for although 'Conquest may give one power', only 'Consent of the People, either tacite ... or explicit' gave one the 'Right to rule a Nation'. Subsequent kingship in England, then, was limited and conditional (pp. 40-I, 45). Here Defoe agreed, writing of William I: 'It was a great while after he had made a Conquest, before he accepted the Crown, and when he did it, it was at the Request, and by the election of the People, and on Conditions, which he swore to, of maintaining their Laws and Privileges. ${ }^{61}$

In Reflections, the goal of maintaining domestic peace by strengthening central authority had not been fully achieved by the reign of Henry VII, when parliament passed legislation making it treason 'to resist the King de Facto' even 'in defence, and to maintain the Right of the King de fure'. This law, Reflections argued, was not as 'unreasonable ... as perhaps it may at first appear: For 'tis an acknowledged Aphorism, That the safety of the People is the Supreme Law; and therefore to be prefered before Titles to Succession'. To resist the new regime, even if in defence of James II, is by 'an uncontestable Maxim of our Law' treasonable (p. 62). This piece of Tudor legislation was referred to in the final pages of the pamphlet in which the author ventured to check the objections of those who could not reconcile support of William III with their oaths of allegiance to James II. By contrast, Defoe's objection was more fundamental, and drawn from belief: subjects should not be made to take oaths for secular advantage. The Reflections' defence of de facto authority also seems some distance from Defoe's insistence that 'It is a Universal Rule, that all Humane Laws are subject to the Divine; and if a Law is made by Humane Power, which contradicts the Laws of God, it is void in its Nature. ${ }^{.62}$

Kings might break their covenants; 'Therefore', continued Reflections, 'it is a point of great concern, to know how far, and when it may be lawful for the Subjects to take the forfeiture for their Kings breach of Covenant' and which actions of James II met those conditions. Reflections was reluctant to let the people judge. The conduct of the Seven Bishops was exactly correct, for' 'twould be a sad World indeed, if every body that thought themselves hardly or unjustly dealt withal, should fly in the face of Publick Authority, and have power to resist the

\footnotetext{
${ }^{60}$ Grotius, Rights of war \& peace (1682), p. 40; Condren, Laweson's Politica, pp. 7I-5; Defoe, The original power of the collective body of the people of England (I702 [for I70I]), in [Defoe], A true collection, I (2nd edn, I705), pp. 134-7, I46, and passim.

${ }^{61}$ [Defoe], fure divino, Bk X, p. II.

${ }^{62}$ Ibid., Bk IV, p. 23.
} 
lawful Magistrate' (p. 48). By contrast, Defoe had no such inhibition, and did not confine resistance to bishops or magistrates: 'If it be ask'd who shall be Judge, 'tis plain God has fix'd the Determination in the Nature of the thing, the Discovery is in every Man's Reach, Nature is the Common Judge. ${ }^{\mathbf{6 3}}$

The author of Reflections therefore tried to specify breaches which even monarchists must acknowledge as 'Forfeitures': 'the selling of them [his Subjects], or betraying them to a Foreign Power and Jurisdiction'. This had been a central tenet of Grotian argument; ${ }^{\mathbf{6 4}}$ Grotius was also used by Defoe, although the point was not unique to him. ${ }^{65}$ By sending an ambassador to Rome, continued Reflections, by receiving the papal nuncio, and by promoting Catholics to high public office, James had risked 'bring[ing] the Nation under the Papal Jurisdiction and Slavery' (pp. 48-9). But in the light of the author's reading of biblical kingship, it was James's reluctance to do battle which most disgraced him. James's flight was the 'first Instance, of any Prince that ever ran away from his Government, and quitted the Crown without striking a stroke for it, and that when he had any Army to defend it' (pp. 63-4). By conniving with Louis XIV and the pope, and especially by fleeing his country after William's landing, James II had failed to protect his people and therefore had forfeited their allegiance.

Reflections then turned to further causes of forfeiture, 'the setting up a False and Spurious Heir in an Hereditary Monarchy; and the overturning all the Establisht Laws, and setting up Arbitrary Power in a limited one' (p. 49). The author's subscription to the Whig 'warming pan' myth demonstrated the seriousness with which he took the hereditary aspect of England's constitution, whereas Defoe later disregarded that myth and interpreted the departure of the infant Prince of Wales to France as a forfeiture as much as James's departure had been. Reflections did not champion the idea that once the contract was broken, Englishmen, like the ancient Hebrews, were free to choose any successor at will. But nor did Defoe. $^{66}$

The number of ways in which James had sought to promote his religion, in violation of 'so many Laws and Statutes', was evidence, in the Reflections, of his pretending to absolute and arbitrary power in a limited monarchy (p. 49). This charge seemed to depend on James II's establishing a pattern of habitual dispensation with the laws as opposed to the occasional infraction of them. 'In the

${ }^{63}$ Ibid., Bk III, p. 20.

64 Available in William Evats (trans.), The most excellent Hugo Grotius his three books treating of the rights of war E peace. In the first is handled, whether any war be just. In the second is shewed, the causes of war, both just and uujust [sic]. In the third is declared, what in war is lawful; that is, unpunishable. With the annotations digested into the body of every chapter (London, I682), pp. 42, 44, 63-4.

${ }_{65}$ [Defoe], Fure divino, Bk III, pp. 26-7.

66 'Nor had it been any Question, but that had King James left a Son in England behind him a Protestant, and claiming the Crown, he would have had it - But had the birth of his Son been unquestion'd here, his carrying him away into France certainly depriv'd him as effectually as it did his Father': ibid., p. vii. 
Case of the Ship-Money', Charles I had assumed powers above the law 'but 'twas the only Instance of his doing it in his whole Reign'. Some subjects successfully contested the matter in court, which proved that 'the King did not think himself above the Law, but submitted to it; so that it seems there was no such thing as the Dispensing Power known in those days, but the Rights of the People were preserved inviolate' (pp. 65-6). Of Charles II, the author wrote only that he 'wished he had had the Power of dispensing with tender Consciences on some particular Emergencies', implying no gross pattern of abuse. Only James II 'ever pretended to have Authority to dispense with, and silence all the Laws of the Nation'; by doing so 'he did at once both Un-king himself and release his Subjects' (p. 5I). This avoided describing I688 as a deposition, and was far more favourable to Charles I than was Defoe. According to the Reflections, it was impossible to 'think the Cases of I648 and I688 Parallel', for Charles I was 'a good King, and true Martyr' (p. 65). Defoe took the opposite view. Charles I's subjects, he wrote, did not dispute 'the Legality of his Title to Govern, but the Legality of his Governing'; hence 'the Comparison is very just' between the Revolution of I688 and 'the Parliament War' of the I640s. The latter was therefore not a 'Rebellion'; indeed those who began it were not responsible for Charles I's death. ${ }^{67}$

A minority of contractarians so defined the contract as to make it a hair trigger for the right of resistance, ${ }^{68}$ but the author of Reflections distanced himself from this source of political instability: 'God forbid that I should attempt to make the Government Precarious, or to make Kings accountable for every little Failure: For as every breach of the Law in a Subject is not Treason, so every violation of it by the Prince is not the forfeiting of his Prerogative' (p. 47). So rarely did breaches reach such sufficient magnitude that, to the author, the reign of James II represented 'the first Instance of it in our Nation'. Worse men had ruled but none had 'attempt[ed], in so many Instances, to destroy the Constitution, and overturn the very Foundation of our Government' (pp. 47-8). Given his praise of 'those Noble Patriots' and 'Legislators' who in the past had defended the people's 'Laws and Liberties' from royal encroachments, the author may have accepted the position of some Protestant resistance theorists who argued that, unlike private citizens, it was magistrates who had a right and duty to demonstrate active vigilance against unlawful actions of their kings (p. 35) ${ }^{69}$ Defoe emphatically gave this role to 'the People' in general; Reflections made a similar point, but in a context that gave it a much less populist meaning.

\footnotetext{
67 Ibid., pp. vii, $\mathrm{x}$.

68 Of authors in defence of the Revolution, only some I6 per cent used contract to justify deposition: Goldie, 'The revolution of I689', p. 490.

69 On Protestant resistance theory, see Robert M. Kingdon, 'Calvinism and resistance theory, I550-I580', in J. H. Burns and Mark Goldie, eds., The Cambridge history of political thought, I450-I70o (Cambridge, I99I), pp. I93-2i8.
} 
Selecting kings was one thing; rejecting them posed more problems, and the author of Reflections adopted a position clearly different from Defoe's. Reflections disavowed wishing to 'exclude God' from state affairs;

And altho God may in his secret Decrees design the making such Persons Kings; yet he makes the People the Instruments of raising them, and 'tis from the People that they immediately receive their Power ... But tho God do not chuse a King by any miraculous Declaration of his Will in the Case, yet (if that will satisfie) I will grant that he may direct and incline the Hearts of the People to chuse one rather than another; and when they once have chose, God certainly does confirm it, so that 'tis not in the Peoples power to chuse again, unless by the King's fault his Power is forfeited, and so it resolves to the People.

Rejecting kings was evidently, for the author, an exceptional event, as it was not for the assertively Nonconformist Defoe. Indeed, Reflections edged closer to the Anglican doctrine of passive obedience (in our terms, civil disobedience).

Was 1688 an act of deposition? Not necessarily, according to Reflections: James II's flight meant that 'if silence and submission may be interpreted consent, he did by that [flight] resign both Crown and Kingdom' to William of Orange (p. 64). According to Reflections, a people should rely on providential deliverance from a king who failed in his duties to God:

nothing else [is] required of us, but to accept of that Deliverance which God himself hath wrought for us. For there is very few that have had any other part to act in this Great Revolution, than That of standing still (as Moses says to the Israelites) and seeing the Salvation of the Lord, Exodus I4. I3.

By implication, the Revolution had not been a successful application of resistance theory; indeed, this was one reason why the turn of events had been 'miraculous' (p. I). Again, this may distance authorship from Defoe whose position, certainly by I706, was far more proactive: men had not just a right but a duty to resist oppression. They were otherwise 'Rebels to the Laws of Providence'. If the king were unjust, the people 'not only may, but must' depose him. Not to do so would frustrate God's purposes for man. For Defoe, 'Prayers and Tears' were not enough: they 'no Revolutions make'. Men must be active: 'till we strive, we Cry to Heaven in vain'. ${ }^{70}$

In respect of content, Reflections had no obvious essential themes unique to Defoe's work. Reflections treated i688 as a providential 'Deliverance' (p. I), a favourite theme of Defoe's, but so did an estimated io per cent of the Williamite pamphlets in the Allegiance Controversy ${ }^{71}$ Reflections was a pamphlet replete with biblical language, history, and imagery, but this was the common coin of debate. Reflections condemned jure divino monarchy and passive obedience (pp. $5^{-6}$ ), but so too did almost all supporters of the Revolution. Reflections disavowed more recent historical enquiries into the origin of monarchy in favour of relying on 'Sacred Writ' (p. 7), but many others besides Defoe at least alluded to Scriptural texts.

70 [Defoe], Fure divino, Bk vIII, p. 30, Bk II, p. I8, Bk v, pp. 6-7, Bk II, pp. I8-I9.

71 Goldie, 'Revolution of I689', p. 490. 
The pamphlet's acceptance of bishops as 'an Order of Men ... Fure Divino' (p. 8) and reference to 'those of the Reformed Party' (p. 65) as another set of people would have to be read as a disguise by Defoe (if he were the author) to win the assent of readers who were of the Church of England, since his own Presbyterianism is clear. But this becomes more unlikely as the argument unfolds, and the author of Reflections condemned the 'Revolution' of I648[/9] as 'intending the Subversion ... of the best and purest Religion in the World' where the Revolution of I688 intended its establishment and preservation (p. 66). Reflections used the notion of an original contract between king and people to show that kings derived their power from the people and so from the laws (pp. 29, 40), but this was an idea shared by some 49 per cent of the identified pro-Revolution pamphlets in the debate; what mattered was the author's unwillingness to allow 'the people' regular access to it. ${ }^{72}$ The textual and substantive case for Defoe's authorship of Reflections upon the late great revolution now looks extremely weak: Defoe instead comes into focus not as, in motivation and origin, a secular politician but as a Nonconformist, first and primarily concerned with the momentous issues of religious toleration. ${ }^{73}$

\section{V}

It was suggested at the outset that the varieties of Whiggism are still often recognized only if they fall within a secular taxonomy. For example, the location of ultimate authority in the people and the consequent status of the Convention Parliament of I689 as a constituent assembly have been identified as the defining characteristics of a republican, Commonwealth position. ${ }^{74}$ Yet this may simplify matters unduly by disregarding both the freethinking identity of John Toland's circle, and the much larger theologically orthodox Nonconformist constituency of the post-I688 Whigs. Defoe's position was not the freethinkers': he did not call for a sweeping redrafting of the constitution. Defoe saw himself as a freeholder, dedicated to social stability, but also as a Trinitarian Dissenter, committed to the true religion represented by his denomination. Yet for religious reasons, the Whig Anglican author of Reflections, probably Robert Eyre, distanced himself from resistance theory; for religious reasons, the Whig Daniel Defoe adopted it. In intellectual composition, the Revolution of I688 and its socially moderate outcome was primarily the result of a conflict between Anglicans and Nonconformists in which freethinkers and republicans played only a smaller part. The taxonomy of political ideologies in late seventeenth-century England that we currently employ is scholarly and sophisticated, but it still remains predominantly secular. It should now be expanded to include the territory that Defoe and his fellow orthodox Nonconformists occupied. ${ }^{75}$

\footnotetext{
72 Ibid.

${ }^{73}$ For a similar re-contextualizing of Locke within debates on religious toleration, see John Marshall, Fohn Locke, toleration and early Enlightenment culture (Cambridge, 2006).

74 Goldie, 'Revolution of I689', pp. 2 II-I2, 2 I4.

75 For other proposed revisions, see Condren, Lawson's Politica, pp. ${ }^{5} 5^{-6}-65$.
} 
Reproduced with permission of the copyright owner. Further reproduction prohibited without permission. 